\title{
PENGEMBANGAN UMKM KERUPUK MAMBAL SEBAGAI WUJUD EKONOMI KREATIF DI DESA MAMBALAN KABUPATEN LOMBOK BARAT
}

\author{
Tri Mulyaningsih ${ }^{1)}$, Rika Aprianti ${ }^{1)}$, Ni Luh Putu Juni Ardianti ${ }^{2)}$, Wandhy Alfian \\ Aswin $^{2)}$, Muhamad Faisal ${ }^{3)}$, Nurul Hikmah ${ }^{3)}$, Nurul Hidayati Deram Keraf ${ }^{3)}$, \\ Muhamad Muhtar Mandele ${ }^{4)}$, Fathul Azis ${ }^{5}$, Mizan Hikami6), Novitarini ${ }^{7)}$ \\ 1)Fakultas Matematika dan Ilmu Pengetahuan Alam, Universitas Mataram \\ ${ }^{2)}$ Fakultas Hukum, Universitas Mataram \\ 3)Fakultas Keguruan dan Ilmu Pendidikan, Universitas Mataram \\ 4)Fakultas Pertanian, Universitas Mataram \\ 5) Fakultas Peternakan, Universitas Mataram \\ 6)Fakultas Ekonomi dan Bisnis, Universitas Mataram \\ 7) Fakultas Kedokteran, Universitas Mataram \\ Jalan Majapahit Nomor 62, Mataram \\ *alamat korespondensi: trimulya@unram.ac.id
}

\begin{abstract}
ABSTRAK
Desa Mambalan merupakan desa tertua yang ada di Kecamatan Gunungsari Kabupaten Lombok Barat. Pada daerah tersebut, terdapat sebuah Usaha Mikro Kecil dan Menengah (UMKM) yang beranggotakan ibu-ibu rumah tangga yang memproduksi kerupuk tepung terigu yang dikenal dengan "Kerupuk Mambal". UMKM tersebut mengalami kelumpuhan, setelah bencana gempa bumi melanda pulau Lombok, dan mengakibatkan area bangunan tempat pembuatan kerupuk runtuh serta fasilitasnya tertimbun oleh reruntuhan bangunan. Tujuan kegiatan pengabdian kepada masyarakat di Desa Mambalan tersebut adalah mengembangkan UMKM kerupuk Mambal sebagai wujud ekonomi kreatif pasca gempa tepatnya di dusun Mambalan desa Mambalan kecamatan Gunungsari kabupaten Lombok Barat. Pengembangan UMKM tersebut dilakuan dengan cara membuat varian cita rasa kerupuk. Varian cita rasa yang ditambahkan adalah ekstrak daun bayam (Amaranthus hybridus L.), ekstrak daun kelor (Moringa oleifera Lam.), ekstrak wortel (Daucus carota L.), dan daging ikan tongkol (Euthynnus affinis). Hasil pelaksanaan kegiatan pengabdian kepada masyarakat dalam pengembangan UMKM Kerupuk Mambal adalah cita rasa baru pada produksi kerupuk yakni cita rasa daun kelor, daun bayam, buah wortel, dan daging ikan tongkol. Berdasarkan minat konsumen terhadap produk varian rasa yang dihasilkan, varian yang paling laku serta yang kurang laku terjual secara berurutan yaitu kerupuk mambal varian rasa kelor dan varian rasa ikan tongkol.
\end{abstract}

Kata kunci: kerupuk mambal, UMKM, desa Mambalan, Kabupaten Lombok Barat 


\section{PENDAHULUAN}

Usaha Mikro Kecil dan Menengah (UMKM) hendaknya senantiasa mendapatkan perhatian berbagai kalangan karena UMKM tersebut adalah bentuk demokrasi ekonomi yang mampu memperpendek ketimpangan antara yang mempunyai modal dengan yang tidak mempunyai modal. Pengembangan UMKM juga perlu dilakukan karena UMKM tersebut merupakan usaha kerakyatan yang dapat bertahan terhadap fluktuasi ekonomi internasional dan mampu menyerap tenaga kerja meski dalam skala kecil (Hasan \& Rizkiana, 2018).

Di Desa Mambalan Kecamatan Gunungsari, Kabupaten Lombok Barat, banyak dijumpai masyarakat yang membuat usaha krupuk Mambal rumahan. Program kemitraan masyarakat Kelompok Usaha Kerupuk Mambal perlu digalakkan, agar terbentuk mitra-mitra usaha yang bergerak dalam produksi kerupuk olahan tepung, di desa tersebut sehingga dapat dibentuk suatu koperasi.

Desa Mambalan merupakan desa tertua yang ada di Kecamatan Gunungsari Kabupaten Lombok Barat. Desa Mambalan merupakan desa yang sangat lengkap akan kebangsawanannya. Desa Mambalan terbagi atas 4 dusun, yaitu dusun Mambalan, dusun Buwuh, dusun
Batu Riti, dan dusun Lilir Barat. Sebagain besar pekerjaan sehari-hari warga desa Mambalan adalah buruh lepas dan petani. Di dusun Mambalan terdapat sebuah UMKM yang beranggotakan para ibu-ibu rumah tangga yang memproduksi kerupuk tepung yang dikenal dengan "Kerupuk Mambal". Kerupuk Mambal tersebut sudah sangat terkenal hingga ke luar pulau Lombok, seperti daerah Bima, Sumbawa dan Dompu.

Bencana gempa bumi melanda pulau Lombok, yang mengakibatkan UMKM di desa Mambalan mengalami kelumpuhan. Bencana ini mengakibatkan area tempat pembuatan kerupuk tersebut roboh dan berbagai fasilitas lainnya mengalami kerusakan akibat tertimpa oleh reruntuhan bangunan. Namun semangat para ibu-ibu tidak rapuh, sehingga untuk sementara waktu tempat UMKM tersebut dibangun lagi, ibu-ibu mencoba memproduksi kerupuk Mambal lagi di rumah masing-masing dengan peralatan seadanya.

Kerupuk Mambal hasil produksi kegiatan UMKM desa Mambal saat ini masih memiliki satu varian rasa yaitu rasa original. Hal tersebut dapat menjadi salah satu kekurangan yang menyebabkan sedikitnya pilihan konsumen sehingga berpengaruh terhadap kecilnya nilai tawar poduk. Hal tersebut harus dicarikan solusinya agar kegiatan UMKM dapat terus 
berjalan dengan baik meskipun dalam situasi yang kurang kondusif akibat adanya bencana gempa bumi

Kegiatan pengabdian kepada masyarakat ini bertujuan untuk membantu pengembangan UMKM Kerupuk Mambal. Aspek yang dikembangkan dalam kegiatan ini adalah memperbanyak varian cita rasa produk. Berbagai macam varian rasa yang dicoba untuk dikembangkan adalah rasa daun kelor, daun bayam, wortel, dan ikan tongkol.

Salah satu alasan memilih varian rasa tersebut adalah bahan yang sangat kaya akan kandungan giz yang sangat berguna untuk kesehatan tubuh kita untuk menjalain rutinitas kehidupan yang ada dibumi. Adapun untuk bahan sayuran merupakan bahan yang ramah lingkungan dan mudah di dapatkan oleh setiap produsen kerupuk mambal, serta untuk menghemat biaya tambahan varian rasa tersebut masyarakat bisa menanamnya dengan memanfaatkan sedikit penkarangan rumahnya. Sedangkan untuk bahan piletan ikan tongkol merupakan ikan yang sangat kaya akan kandungan gizi, diantaranya meningkatkan fungsi kerja otak, antioksidan, menjaga kadar elktrolit tubuh, basih banyak lainnya manfaat ikan tongkol.

\section{METODE KEGIATAN}

Jenis pengabdian yang dilakukan adalah "Pengembangan UMKM Kerupuk Mambal Sebagai Wujud Ekonomi Kreatif di Desa Mambalan Kecamatan Gunungsari Kabupaten Lombok Barat".

Kegiatan pengabdian kepada masyarakat dilakukan di desa Mambalan. Untuk pengembangan UMKM pembuatan krupuk Mambal dengan 4 varian cita rasa terpusat di dusun Mambalan desa Mambalan kecamatan Gunungsari kabupaten Lombok Barat, Lombok. Kegiatan ini banyak melibatkan para ibu-ibu dan ada juga bapak-bapak yang bekerja pada UMKM krupuk Mambal pada tingkat menengah.

Alat dan bahan yang di butuhkan dalam pengabdian pengembangan UMKM kerupuk Mambal dalam segi varian rasa yaitu: baskom 5 buah, blender, dandang besar, nampan 5 buah, saringan, sendok. Bahan utama dalam pembuatan kerupuk, antara lain: tepung kanji, tepung terigu, bawang putih dan bahan tambahan yang dibutuhkan, yaitu: varian rasa yang terdiri dari daun bayam, daun kelor, wortel, filet ikan tongkol.

Prosedur pembuatan kerupuk mambal tersebut dibagi menjadi tiga tahapan. Tahapan pertama yaitu: pembuatan ekstrak varian rasa, dengan cara menghaluskan bahan 
(daun kelor, daun bayam, wortel dan filet ikan) secara terpisah menggunakan blender. Selanjutnya bahan yang telah halus diambil air ekstraknya, yang akan digunakan sebagai tambahan untuk varian rasa dengan saringan. Tahapan berikutnya tepung terigu, tepung kanji yang telah diayak dan bumbu bumbu yang telah dihaluskan dituangkan kedalam baskom besar. Kemudian diaduk merata, selanjutnya diambil sebagian adonan tepung dan masukkan kedalam 4 baskom kecil, untuk dicampurkan dengan hasil saringan ekstrak varian rasa yang digunakan, baik daun kelor, baun bayam, wortel maupun ikan.

Tahapan kedua yaitu pembuatan krupuk dengan cetakkan nampan. Cara pembuatannya adalah sebagai berikut: adonan krupuk dituang pada punggung nampan, lalu diratakan sehingga membentuk lapisan yang tipis, selanjutnya nampan tersebut di kukus, hingga adonan berubah warna dan tekturnya (masak). Nampan diangkat dan lemparan krupuk pada punggung nampan diangkat dari nampan, kemudian di potong kecil-kecil dan selanjutnya di jemur. Tahapan terakhir yaitu Penggorengan kerupuk dan pengemasan.

\section{HASIL DAN PEMBAHASAN}

Kegiatan pengabdian kepada masyarakat ini menghasilkan produk kerupuk mambal dengan varian rasa kelor, varian rasa bayam, varian rasa wortel, dan varian rasa ikan tongkol. Analisis dan penjelasan dari produk yang dihasilkan sebagai berikut

1. Kerupuk mambal varian rasa kelor (Moringa oleifera Lam.)

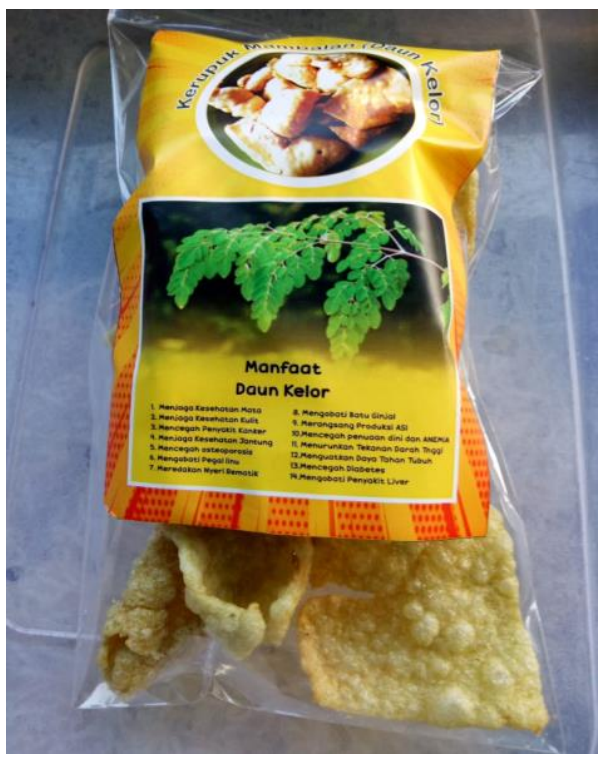

Gambar 1. kerupuk mambal varian rasa kelor.

Pada kerupuk mambal varian rasa kelor warna sebelum digoreng dan setelah digoreng memiliki warna yang sedikit berbeda dari sebelumnya. Kerupuk mambal varian rasa kelor sebelum di goreng warnanya sangat hijau, hal tersebut karena daun kelor banyak mengandung klorofil. Setelah digoreng warnanya jauh berubah menjadi kuning kehijauan. Daun kelor juga mengandung senyawa fitokimia seperti flavonoid, saponin, dan tanin yang berperan sebagai antibakteri (Busani dkk., 2012).

2. Kerupuk mambal varian rasa bayam (Amaranthus hybridus L.) 
Kerupuk mambal varian rasa daun bayam tidak jauh berbeda dengan kerupuk mambal varian rasa kelor. Sama-sama memiliki warna hijau sebelum digoreng, akan tetapi kandungan klorofil pada bayam lebih sedikit dibandingkan dengan daun kelor. Sehingga warna kerupuk mambal varian rasa bayam berwarna hijau kemuda-mudaan. Kandungan gizi per $100 \mathrm{~g}$ meliputi energy $100 \mathrm{~kJ}$, karbohidrat 3,4 g, protein 2,5 g, beta carotene $4,1 \mathrm{mg}$, Viamin B kompleks $0,9 \mathrm{mg}$, Vitamin C $52 \mathrm{mg}$ (Grubben, 1994). Vitamin $C$ sangat penting untuk tubuh manusia. Manfaatnya antara lain dapat mengobati berbagai macam gangguan pada manusia, mulai dari kanker, diabetes, infeksi virus dan berbagai jenis bakteri, serta memperlambat penuaan dini (Maiyo, et al., 2010 ). Menurut Peter \& Gandhi (2017), dari 13 jenis Amaranthus termasuk $A$. hybridus paling sedikit memiliki 10 manfaat, yakni sebagai anti malaria, antinociceptive, anticancerous, antioxidant dan antiinflammasi, anti=diabetic, antimikrobial, anti-depresan, hepatoprotektif, cardio-protektif dan gastro-protektif.

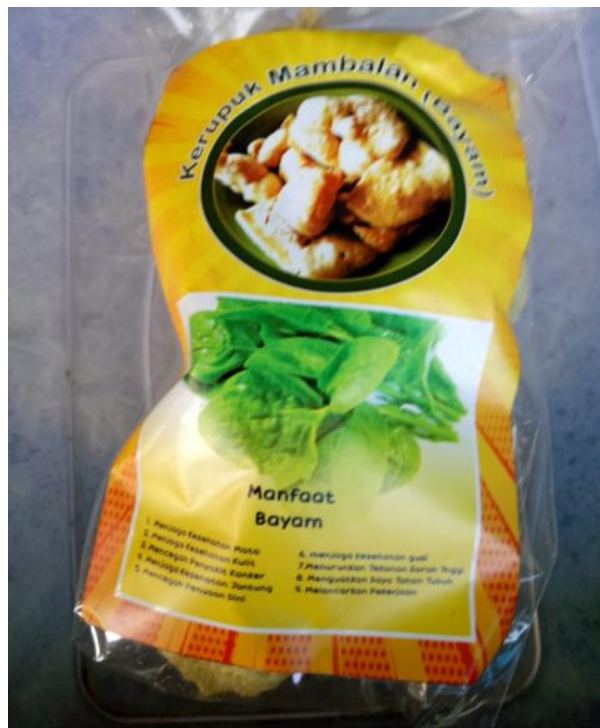

Gambar 2. kerupuk mambal varian rasa bayam

3. Wortel (Daucus carota L.)

Pada kerupuk mambal varian rasa wortel, warna sebelum digoreng jauh berbeda dengan varian rasa sebelumnya yaitu warna orange. Dan setelah di goreng warnanya menjadi kuning kemerah-merahan. Warna orange pada wortel tersebut diakibatkan oleh kandungan zat beta karoten.

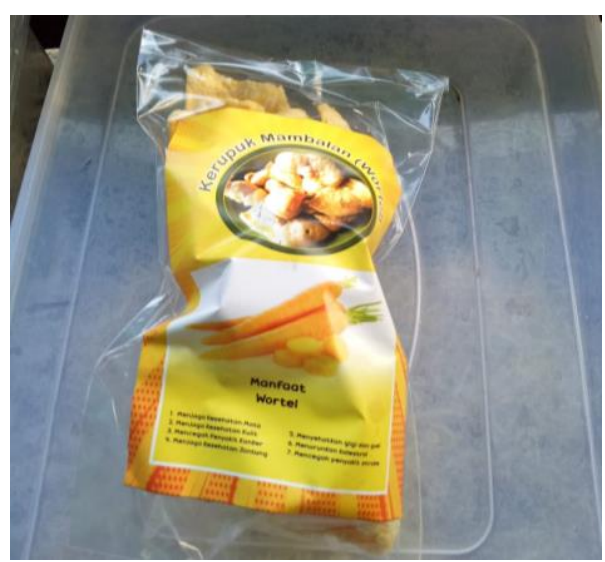

Gambar 3. kerupuk mambal varian rasa wortel. 
Beta karoten merupakan senyawa yang akan dikonversikanmenjadi vitamin A, semakin orange atau merah warna wortel maka semakin tinggi kandungan vitamin A. Wortel tergolong memiliki kandungan serat yang tinggi, yaitu $4 \mathrm{~g}$ per $100 \mathrm{~g}$ bahan (Rusilanti dan Kusharto, 2007). Penambahan wrtel pada nuget tempe dapat meningkatkan kadar air, serat, abu, protein, hedonic rasa, tekstur dan berpengaruh tidak nyata terhadap hedonic warna dan aroma (Wibowo, dkk., 2014).

\section{Ikan Tongkol (Euthynnus affinis)}

Kerupuk mambal varian rasa ikan tongkol merupakan salah satu varian rasa daging yang digunakan. Warna sebelum dan sesudah di goreng tidak jauh berbeda yaitu warna kecoklat-coklatan. Untuk varian rasa Ikan tongkol ini memiliki perbedaan rasa yang sangat jauh dari ketiga varian rasa yang ada, yaitu baunya sedikit amis dan sedikit asin. Hal ini disebabkan filet yang digunakan berupa pindang ikan tongkol yang telah diberi garam, seharusnya menggunakan filet ikan tongkol segar, dan sebelum filet diblender terlebih dahulu direndam dengan air jeruk nipis, sehingga rasa tidak asin dan bau tidak amis.

Ikan tongkol sangat baik digunakan sebagai salah satu varian rasa karena memiliki kandungan gizi yang tinggi yang dapat meningkatkan gizi masyarakat, antara lain: kadar air 71-76,76\%, protein 21.6-26,3\%, lemak 1,3-2,7\%, mineral (kalsium, fosfor, besi dan sodium), retinol (vitamin A), thiamin, riboflavin dan niasin (vitamin B) (Deslianti, dkk., 2016).

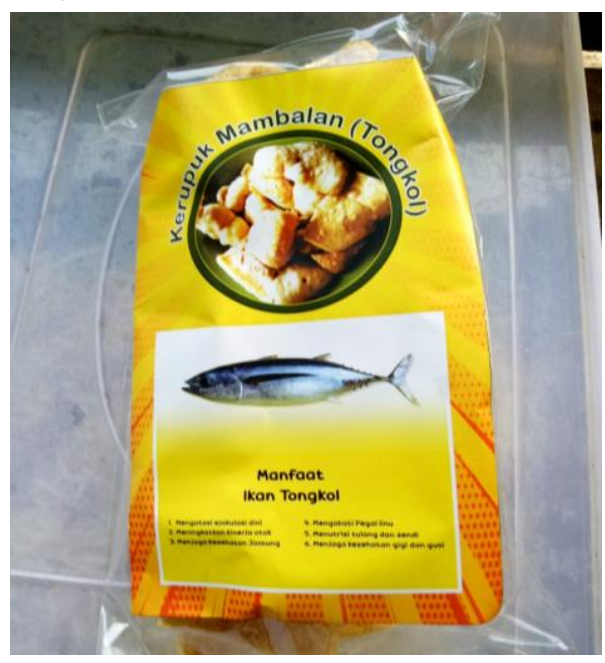

Gambar 4. Kerupuk mambal varian rasa ikan tongkol

Hasil dari produksi krupuk varian rasa selanjutnya dikemas dalam kemasan plastic seperti terlihat pada Gambar 1-4. Dari hasil tersebut didapatkan 30 kemasan (bungkus) untuk setiap varian rasa seperti yang tertera pada Tabel 1 .

Tabel 1. Hasil penjualan krupuk Mambal dengan 4 varian cita rasa.

\begin{tabular}{|c|c|c|c|}
\hline \multirow{2}{*}{$\begin{array}{c}\text { Varian } \\
\text { rasa }\end{array}$} & Jumlah & Laku & sisa \\
\hline & \multicolumn{3}{|c|}{ (bungkus) } \\
\hline Kelor & 30 & 30 & 0 \\
\hline Bayam & 30 & 27 & 3 \\
\hline Wortel & 30 & 24 & 6 \\
\hline $\begin{array}{l}\text { Ikan } \\
\text { tongkol }\end{array}$ & 30 & 20 & 10 \\
\hline
\end{tabular}


Berdasarkan table di atas, dapat diketahui bahwa produksi kerupuk mambal varian rasa yang paling digemari oleh konsumen adalah varian rasa kelor dan bayam hal tersebut dikarenakan rasa dari kerupuk ini gurih, dan enak serta kandungan nutrisi yang ada didalam kedua bahan tersebut cukup kompleks. Varian rasa wortel juga cukup diminati oleh konsumen, karena warna yang dihasilkan dari penambahan wortel ke adonan kerupuk mambalan cukup bagus, sehingga mampu menarik minat masyarakat untuk mencobanya. Selain itu rasa dari kerupuk ini enak dan sangat renyah. Sedangkan krupuk mambal varian rasa ikan tongkol memiliki rasa yang asin dikarenakan bahan baku yang digunakan sudah matang direbus dan telah ditambahkan garam, selain itu penambahan ikan tongkol ke adonan kerupuk menyebabkan bau yang amis dan warnanya agak coklat, menurut beberapa konsumen namun ada juga konsumen yang menyukai rasanya.

\section{Kendala Dalam Pengabdian Kepada Masyarakat}

Beberapa kendala dalam proses pembuatan kerupuk Mambal varian rasa tersebut adalah masih minim dan kurangnya penambahan modal yang digunakan untuk membeli bahan yang akan dijadikan varian rasa, terutama wortel dan ikan tongkol. Dan kendala dalam proses penambahan varian rasa, $\mathrm{Hal}$ itu menyebabkan tidak semua produsen mau menerima inovasi yang ditawarkan.

\section{KESIMPULAN DAN SARAN}

Dari hasil Pengabdian Kepada Masyarakat ini dapat disimpulkan bahwa pengembangan UMKM Kerupuk Mambal dengan empat varian rasa (kelor, bayam, wortel dan ikan tongkol) terlaksana baik dan dapat diterima oleh produsen dan konsumen. Dari semua varian rasa yang digunakan tingkat keminatan konsumen bervariasi. Kerupuk mambalan varian rasa yang paling diminati oleh konsumen secara berturut-turut yaitu kerupuk mambal varian rasa kelor, bayam dan wortel dan varian rasa kerupuk mambalan yang kurang diminati yaitu ikan tongkol.

\section{UCAPAN TERIMA KASIH}

Terimakasih kami ucapkan kepada semua pihak yang telah membantu mensukseskan semua program kerja yang telah kami programkan selama di desa Mambalan kecamatan Gunungsari, terutama kepada Lalu Ahyar Rosyidi, S.Pdi selaku sekertris desa Mambalan. Baiq Hilmiah selaku bendahara desa. Lalu Sanusi selaku kadus Batu Riti. Lalu Riyan selaku kadus Buwuh. Datu Jana Supardi 
selaku kadus Mambalan. Dinde Lusi, Dinde Erna, dan Datu Sugir selaku produsen Krupuk yang sudah membantu dan menerima program kami

\section{DAFTAR PUSTAKA}

Deslianti, B., A. Kurnia,\&W.H. Muskita. 2016. Studi penggunakan tepung ikan layang (Decapterus russelli) dengan tepung ikan tongkol (Euthynnusa affinis) dalam pakan terhadap kecernaan juvenil udang Vaname (Litopenaeus Vannamei). Media kuatika, 1 (4) : 261-269.

Hasan, B., A. Rizkiana. 2018. Varian produksi, manajemen keuangan dan pemasaran usaha mikro kerupuk kerrang Madurasa di kabupaten Bangkalan. International Journal of Community Service Learning 2 (3): 133-140.
Maiyo, Z.C., R.M. Ngure, J.C. Matasyoh \& R. Chepkorir. 2010. Phytochemical constituents and antimicrobial activity of leaf extracts of three Amaranthus plant species. African Journal of Biotechnology 9 (21): 31783182.

Peter, K., P. Gandhi. 2017. Rediscovering the therapeutic potential of Amaranthus species: A review. Egyption Journal of Basic and Aplied Sciences 4: 196-205.

Rusilanti \& C. M. Kusharto. 2007. Sehat dengan Makanan Berserat. AgroMedia Pustaka. Jakarta Selatan. 60p.

Wibowo, A., F. Hamzah, \& V. S. Johan. 2014. Pemanfaatan wortel (Daucus carota L.) dalam meningkatkan mutu nugget tempe. SAGU 13(2): 2734 